\title{
Impact of supermarket on small retail outlets (Mom and pop stores) in Hyderabad
}

\section{SUDIP KUMAR DAS, SEEMA NATH AND KULDEEP CHOUDHARY}

Received : 18.03.2017; Revised : 01.08.2017; Accepted : 15.08.2017

\begin{abstract}
The present study impact of supermarket on small retail outlets (mom and pop stores) was conducted in Hyderabad city during the year 2011. Majority of retailers (42\%) profit and turnover decreased. 34\% of retailers profit and turnover increased and $24 \%$ of retailers business remained same after the entry of supermarkets in the area Majority of retailers (52\%) expressed that their profit and turnover decreased because of organized retail. Another $20 \%$ felt the decreased because of other unorganized outlets started in the area and rest $29 \%$ experienced decreased due to other family reason. Most of the respondents (80\%) extended credit to their customer which is the main reason to retain and hold the customer. No negative impact on employment was found due to the opening of more organized outlets in the city. Nearly $26 \%$ of small retailers increased the number of employees and another $74 \%$ having maintained same number of employees. Only a few number of retail shops have been closed as reported by the sampled retailers. The closing of those few retail shops is not because of organized retail but for other reason. Most of the retailers practiced different strategy like 10\% retailers reduced prices, $12 \%$ reduced their expenses and $14 \%$ added new product lines to compete with the supermarkets.
\end{abstract}

KEY WORDS : Supermarket, Small retail, Profit, Turnover, Employment

How to cite this paper : Das, Sudip Kumar, Nath, Seema and Choudhary, Kuldeep (2017). Impact of supermarket on small retail outlets (Mom and pop stores) in Hyderabad. Internat. J. Com. \& Bus. Manage, 10(2) : 71-76, DOI: 10.15740/HAS/IJCBM/10.2/71-76.

\section{MEMBERS OF THE RESEARCH FORUM}

Correspondence to:

SUDIP KUMAR DAS, Department of Agri business Management, College of Agriculture, Acharya, N.G. Ranga Agricultural University, Rajendranagar, HYDERABAD (TELANGANA) INDIA

\section{Authors' affiliations:}

SEEMA NATH, Department of Agri business Management, College of Agriculture, Acharya, N.G. Ranga Agricultural University, Rajendranagar, HYDERABAD (TELANGANA) INDIA

KULDEEP CHOUDHARY, ASPEE Agribusiness Management Institute, Navsari Agricultural University, NAVSARI (GUJARAT) INDIA 